\title{
Çocukta Serebral Tutulumun Eşlik Ettiği Kardiyak Kist Hidatik: Olgu Sunumu
}

\section{Cardiac Hydatid Cyst Associated with Cerebral Involvement in a Child: Case Report}

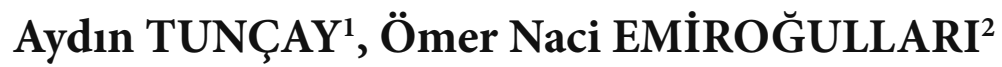

${ }^{1} \mathrm{MD}$, Erciyes University Faculty of Medicine, Department of Cardiovascular Surgery, KAYSERI

${ }^{2}$ Prof. Dr. Erciyes University Faculty of Medicine, Department of Cardiovascular Surgery, KAYSERİ

\section{$\ddot{O ̈}_{z}$}

Kalpte kist hidatik nadirdir ve genellikle erişkinlerde görülür. Nonspesifik semptom ve klinik bulguların değişkenliğine bağlı olarak tanı koymak güç olabilir. Önce beyindeki daha sonra kalpteki kistin aşamalı olarak ameliyat edildiği 12 yaşında bir çocukta gördüğümüz serebral tutulumun da eşlik ettiği interventriküler septum localize kist hidatik olgusunu sunuyoruz.

Anahtar Kelimeler: Kardiyak hidatik kist, çocukluk çağı, serebral kist hidatik

\section{Abstract}

Cardiac hydatid cyst is rare and usually occurs in adults. The diagnosis of cardiac cyst hydatid may be difficult due to nonspecific symptoms and varying clinical presentations. Here, we present a 12-year-old girl with cardiac (interventricular septum) and cerebral hydatid cyst, who was successfully managed with a staged surgical treating the cerebrum first, followed by the heart.

Key Words: Cardiac hydatid cyst, childhood, cerebral hydatid cyst

\section{INTRODUCTION}

Hydatid disease is a parasitic infestation caused by Echinocccus granulosus and less frequently E c h i n o c o c c u s multilocularis. In humans, the disease most commonly involves the lung and the liver; cardiac involvement is very rare and occurs in less than $2 \%$ of cases. Cyst can affect any region of the heart, but the left ventricle appears to be involved

Figure 1. Two-dimensional echocardiography (1a) and MR (1b) showed a hydatid cyst arising from the interventricular septum.

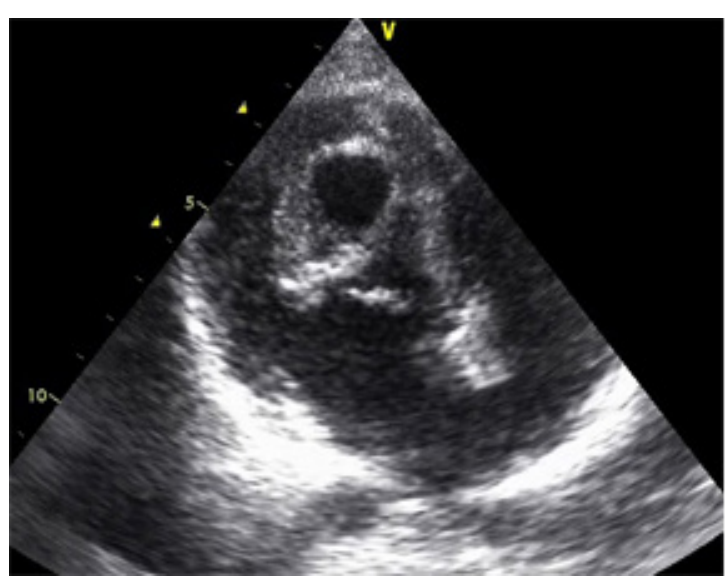

Fig 1a

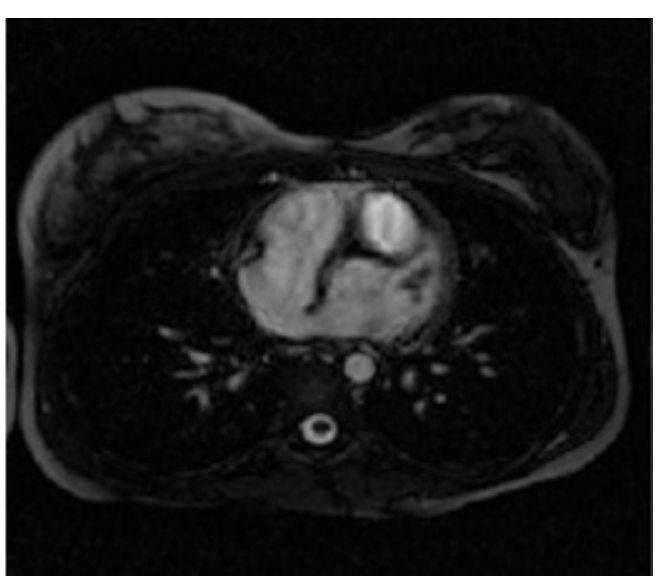

Fig $1 \mathrm{~b}$ most frequently $(55 \%$ to $60 \%)$. Involvement of the interventricular septum is reported in $10 \%$ to $20 \%$ of cases and homing of the parasite in the right atrium and right ventricle is seen in $4 \%$ and $15 \%$ of cases, respectively. The left atrium, pulmonary artery, pericardial, and endocardial involvement have also been reported (1-7).

In this report, we describe a case interventricular localized cardiac hydatid cyst associated with cerebral involvement.

\section{CASE REPORT}

A 12-year-old girl was admitted to Emergency Department of Aksaray State Hospital with complaints of head ache, vomiting, nausea, black out of consciousness, low vision in left eye. The severity of the head ache

$\begin{array}{llll}\text { İletişim: } & \begin{array}{l}\text { Dr. Ö. Naci Emiroğulları, Erciyes Üniversitesi } \\ \text { Fakültesi Kalp ve Damar Cerrahisi AD, Kayseri }\end{array} & \begin{array}{l}\text { Tel } \\ \text { E-Posta } \quad\end{array} & 05426771612 \\ & & \text { Geliş Tarihi : } & 24.05 .2018 \\ & & \text { Kabul Tarihi : } 26.06 .2018\end{array}$

worsened in two months. Glosgow coma scale was 1011. Cranial CTI (computerized tomography imaging) showed a cystic mass which caused midline shift, was in frontal lobe. The patient was operated by neurosurgery department in the same hospital. After operation, echocardiography and thoracic and abdominal MR (magnetic resonance) were made for screening. These both techniques showed approximate $3 \times 4 \mathrm{~cm}$ hydatid cyst arising from the interventricular septum to the left ventricular cavity (Figure 1a, b). So the patient was referred to our clinic.

Her physical examination revealed normal findings, and laboratory data were normal range. The patient underwent median sternotomy and was placed on cardiopulmonary bypass with aortic arterial and bicaval venous cannulation. The aorta was cross-clamped.
$\mathrm{Te}$
Kabul Tarihi : 26.06 .2018 
Isothermic, potassium-enriched blood cardioplegic solution was used. The left atrium was vented through the right upper pulmonary vein. The left ventriculotomy incision to excise the cyst was parallel to and on the left side of the left anterior descending coronary artery, to avoid damaging that vessel. The intervenricular cyst was $2 \mathrm{~cm}$ distances both mitral valve and left ventricular apex. The surrounding area of the cyst was covered by gauzes containing hypertonic saline. Cyst fluid was aspirated and replaced by hypertonic saline to reduce the parasite load and the risk of infection spreading as a result of cyst rupture. After 5 minutes, the cyst was opened and daughter cysts were gently removed (Figure $2 \mathrm{a}, \mathrm{b}, \mathrm{c}$ ). The cyst was then washed out with normal (0.9\%) saline. Capitonnage was performed, and the incision was closed with the use of Teflon felt. Histopathologic examination confirmed the diagnosis of hydatidosis. The postoperative period was uneventful, and the patient was discharged on the 8th postoperative day. The patient was treated with albendazole to prevent recurrence. At the routine follow-up examination 24 months postoperatively, the patient was asymptomatic, and with no trace of cysts on echocardiography (Fig-3).

Figure 2. Intraoperative photographs show hydatid cyst after left ventriculotomy (a), after cystotomy (b), and after daughter cysts were removed (c).
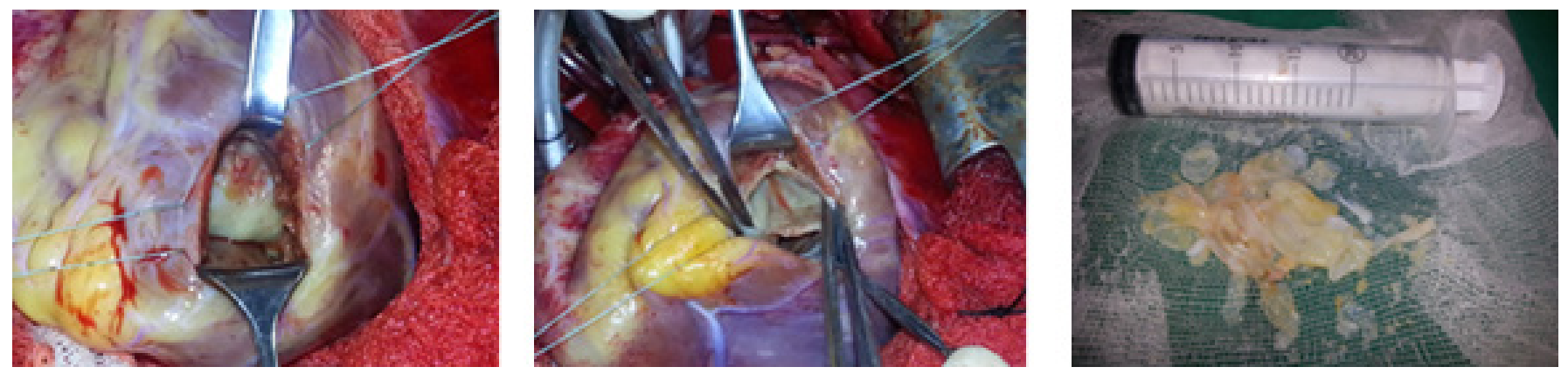

are definitive hosts, whereas sheep and other ruminants are intermediate hosts. Humans are infected by ingestion of food or water contaminated by dog feces containing the eggs of the parasite. The larva reaches the myocardium through the coronary circulation, but the intestinal lymphatic, thoracic duct, superior and inferior vena cava, large intestine, and hemorrhoidal veins may also be the pathway $(1,4,5)$.

The most common sites of hydatid cysts are the liver (in $50 \%-70 \%$ of cases), lungs $(5 \%-30 \%)$, muscles $(5 \%)$, bones $(3 \%)$, kidneys (2\%), spleen (1\%), and brain (1\%). Cardiac hydatid cysts are rare. The coronary circulation is the main pathway by which the parasitic larvae reach the heart. Because of a rich coronary blood supply, the left ventricle is the site of cardiac hydatid cysts in 55\% to $60 \%$ of cases. Less frequently involved are the right ventricle (10\%-15\% of cases), pericardium (7\%), pulmonary artery $(6 \%-7 \%)$, left atrium $(6 \%-8 \%)$, right atrium $(3 \%-4 \%)$, and interventricular septum (4\%). Although cough is typically the chief clinical symptom of hydatid disease, cardiac hydatid cysts are usually asymptomatic, especially in their early stages, and only $10 \%$ of patients have clinical symptoms (1-7). The effects of cysts are usually due to pressure, arrhythmias, angina, valvular
Figure 3. Postoperative two-dimensional echocardiography shows normal findings

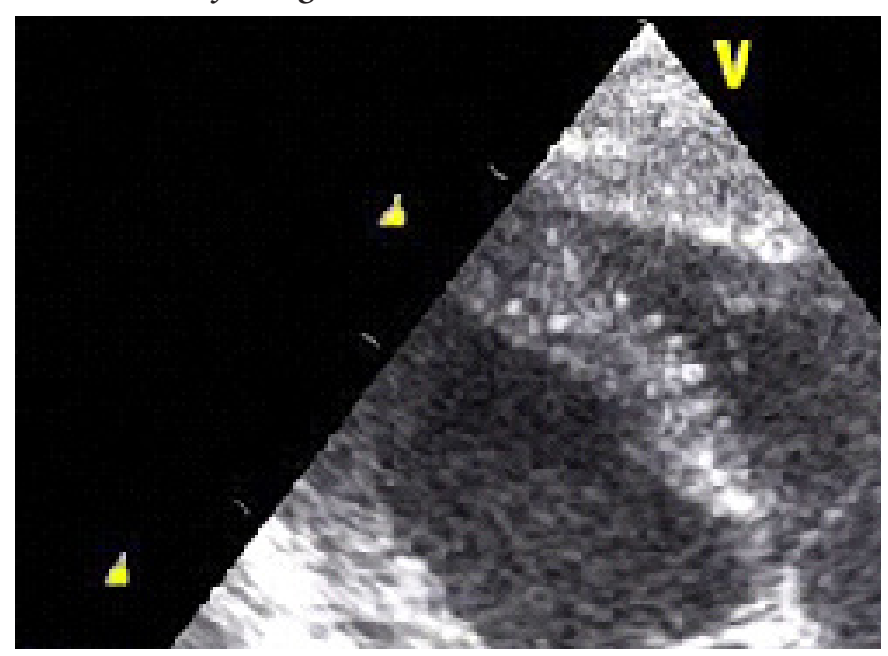

\section{DISCUSSION}

Hydatid disease is a parasitic infestation caused by Echinocccus granulosus and less frequently Echinococcus Multilocularis. Dogs or other carnivores 
1. Emiroğulları N, Üzüm K, Üstünbaş HB, Andaç H, Taşdemir K. Primary Cardiac echinococcosis in childhood. Scan J Thor Cardiovasc Surg 1995;29: 153-156

2. Yasim A, Ustunsoy H, Gokaslan G, Hafız E, Arslanoglu Y. Cardiac Echinococcosis: A Single-Centre Study with 25 Patients. Heart, Lung and Circulation 2017;2 6: 157-163.

3. Yllmazer MM, Devrim İ, Tavlı V. Cardiac hydatid cyst associated with multiple organ involvement. Acta Cardiol 2011; 66: 87-88.

4. Molavipour A, Javan H, Moghaddam AA, Dastani M, Abbasi M, Ghahramani S. Combined medical and surgical treatment of intracardiac hydatid cysts in 11 patients. J Card Surg 2010; 25: 143-146.
5. Wadhawa V, Shah J, Doshi C, Ramani J, Lakhia K, Rathod $D$, et al. Surgical overview of cardiac echinococcosis: a rare entity. Interact Cardiovasc Thorac Surg 2018; 27: 191-197

6. Tefera E, Knapp J, Teodori M. Hydatid cyst of the interventricular septum. Glob Cardiol Sci Pract. 2017; 2017: e201709

7. Kahlfuss S, Flieger RR, Roepke TK, Yilmaz K. Diagnosis and treatment of cardiac echinococcosis. Heart 2016; 102: 1348-1353. 